\title{
Use of Root-end Filling Materials After Root-end Resections Among Oral Surgeons: A National Survey
}

\author{
Çene Cerrahları Arasında Apikal Rezeksiyon Sonrası Kök-ucu \\ Dolgu Maddesi Kullanımı: Ulusal Anket Çalışması
}

\author{
(1) Makbule Bilge Akbulut ${ }^{1}$, (1) Selen İnce Yusufoğlu ${ }^{2}$, (1) Dilek Menziletoğlu ${ }^{3}$ \\ ${ }^{1}$ Necmettin Erbakan University Faculty of Dentistry, Department of Endodontics, Konya, Turkey \\ ${ }^{2}$ Ankara Yıldırım Beyazıt University Faculty of Dentistry, Department of Endodontics, Ankara, Turkey \\ ${ }^{3}$ Necmettin Erbakan University Faculty of Dentistry, Department of Oral and Maxillofacial Surgery, Konya, Turkey
}

Keywords

Apical resection, calcium silicate-based materials, mineral trioxide aggregate, oral surgeon, root-end filling

Anahtar Kelimeler

Apikal rezeksiyon, kalsiyum silikat içerikli materyal, mineral trioksit agregat, çene cerrahı, kök-ucu dolgusu

Received/Geliş Tarihi : 11.06 .2020

Accepted/Kabul Tarihi : 07.09.2020

doi:10.4274/meandros.galenos.2020.94830

Address for Correspondence/Yazışma Adresi: Makbule Bilge Akbulut MD,

Necmettin Erbakan University Faculty of Dentistry, Department of Endodontics, Konya, Turkey

Phone : +90 33222000 26-3166

E-mail :dt.bilge@yahoo.com

ORCID ID: orcid.org/0000-0001-9082-3120

(C) Meandros Medical and Dental Journal, Published by Galenos Publishing House.

This is article distributed under the terms of the Creative Commons Attribution NonCommercial 4.0

International Licence (CC BY-NC 4.0).

\begin{abstract}
Objective: The placement of a root-end filling material to seal the end of the root canal is one of the most important procedures in apical surgery. In Turkey, root-end surgeries are most often performed by oral surgeons. This national survey aimed to evaluate and describe the use of root-end filling materials after apical resections among oral surgeons.

Materials and Methods: A web-based survey consisting of nine questions was prepared using Google forms, and the link to the survey was sent to the oral surgeons. The questionnaire collected information regarding age, gender, level of education, number of years of practice, type of institution, average frequency of root-end resections performed per month, whether root-end filling material was used after apical resections, type of the root-end filling material used and reasons for not placing a root-end filling material. Data was expressed as percentages and frequency rates. Chi-square test was used to identify associations between the usage patterns and surgeons' demographics.

Results: A total of 155 questionnaires were returned. Most of the oral surgeons surveyed (82.6\%) performed root-end resections at a rate of $<20 \%$ per month. Our data indicated that $47.7 \%$ of the respondents routinely used a root-end filling material after an apical resection, whereas 9\% of them never used it. Most of the participants who used root-end filling material preferred a calcium-silicate-based material (95.1\%).

Conclusion: According to the survey results, a significant number of oral surgeons still do not use a root-end filling material after apical surgery for various reasons. Oral surgeons' knowledge on this topic should be improved.
\end{abstract}

Öz

Amaç: Kök kanal sonlanmasını kapatmak amacıyla kök-ucu dolgusu yerleştirme işlemi apikal cerrahinin önemli basamaklarından birisidir. Ülkemizde kök-ucu cerrahisi işlemini çoğunlukla çene cerrahları gerçekleştirmektedir. Bu ulusal anketin amacı çene cerrahlarının apikal rezeksiyon sonrası kök-ucu dolgu maddesi kullanımını değerlendirmek ve sunmaktır. 
Gereç ve Yöntemler: Google formlar aracılığıyla 9 sorudan oluşan web-tabanlı bir anket hazırlandı ve anketin URL bağlantısı çene cerrahlarına gönderildi. Hazırlanan ankette katıımcının yaş, cinsiyet, öğrenim durumu, mesleki deneyim, kurum, aylık tedavi sayısına göre kök-ucu rezeksiyonu yapma sıklı̆ı̆, apikal rezeksiyon sonrası kök-ucu dolgu maddesi kullanıp kullanmadığı, kullanılan kök-ucu dolgu maddesi çeşidi ve kök-ucu dolgu maddesi kullanmama nedenleri bilgileri sorulmaktaydı. Veriler yüzde ve sıklık oranları şeklinde ifade edildi. Kullanım paternleri ve cerrah demografikleri arasındaki ilişkiyi belirlemek için ki-kare testi kullanıldı.

Bulgular: Toplamda 155 ankete geri dönüş yapıldı. Anketi yanıtlayan çene cerrahlarının çoğu $(\% 82,6)$ apikal rezeksiyon işlemini ayda $<\% 20$ oranında gerçekleştirmektedir. Çalışmadan elde ettiğimiz veriler çene cerrahlarının \%47,7'sinin apikal rezeksiyondan sonra rutin olarak kök-ucu dolgu maddesi kullandığını ve \%9'unun ise hiç kök-ucu dolgu maddesi kullanmadığını gösterdi. Kök-ucu dolgu maddesi kullanan çene cerrahlarının büyük çoğunluğu kalsiyum-silikat içerikli materyal tercih ettiğini bildirdi $(\% 95,1)$.

Sonuç: Bu anket sonuçları değerlendirildiğinde, azımsanmayacak sayıda çene cerrahının çeşitli sebeplerden dolayı hala apikal rezeksiyondan sonra kök-ucu dolgu maddesi kullanmadığı görülmektedir. Bu konu ile ilgili olarak çene cerrahlarının bilgisi geliştirilmelidir.

\section{Introduction}

Endodontic surgery is indicated for the treatment of apical periodontitis in cases that did not heal after nonsurgical retreatment or in cases in which other factors could not be eliminated, such as a complicated canal anatomy, extraradicular infection, and procedural errors responsible for the failure of the endodontic therapy. Root-end surgery (apicoectomy) is the excision of the root tip of a tooth and the attached pathological periapical tissues. The success rate of modern endodontic surgery has been reported to be $91.6 \%$, the failure rate is $4.7 \%$, and $3.7 \%$ of the cases showed uncertain healing (1).

The procedure for root-end surgery includes the surgical removal of the periapical lesion, a root-end resection, root-end cavity preparation, and root-end filling (2). The aim of root-end filling placement is the complete sealing of the root canal system and the prevention of bacterial ingress into the periradicular tissues. Some earlier research has reported that the healing period is independent from the root-end filling placement, and this has supported the view that a high standard of cleaning and obturation of the root canal after a root-end resection, without rootend filling placement, is adequate $(3,4)$. However, more current studies have favored an apicoectomy procedure, including the placement of root-end filling following the root-end resection because placing a bacterial and toxin-tight root-end filling enhances the success of root-end surgery $(5,6)$.

Numerous materials have been used for root-end filling in the past, including amalgam, intermediate restorative material (IRM), glass ionomer cement, super ethoxy benzoic acid, Cavit, compomer, and composite resin (7). Mineral trioxide aggregate (MTA), the precursor of calcium silicate-based materials, has shown good sealing ability, material stability, biocompatibility, and hard tissue induction capacity (8-10). Because of its many advantageous properties, MTA has become the "gold standard" for root-end filling (7). Moreover, novel brands of calcium silicatebased materials are being developed and introduced into the market.

In Turkey, most often oral surgeons rather than endodontists tend to perform root-end surgery. Since no study has determined the frequency of the use of root-end filling material in Turkey, the goal of this national survey was to evaluate and present the use of root-end filling material after apical resections among oral surgeons, as well as the types of root-end filling materials that they prefer.

\section{Materials and Methods}

This study was approved by the Human Ethics Committee of the Institutional Review Board (protocol no: 19.04.2019-49). A 9-question survey (Table 1) was formulated using Google forms, and the uniform resource locator (URL) link of the survey was sent via social media to oral surgeons and residents training in a maxillofacial surgery department in Turkey. No reminder message was sent, and only those responses delivered within 4 weeks were accepted for analysis.

\section{Statistical Analysis}

A sample size calculation was not applicable given the descriptive nature of the study design, and the survey results were presented as percentages and frequency rates. Chi-square test was used to test the significance of possible associations. $P$ value was set at 0.05 . 


\section{Results}

From the 200 surveyed oral surgeons and residents, 155 participants completed the survey with a $77.5 \%$ response rate. The mean age of the respondents was 30.28 years old, and it ranged from 24 to 53 years old. Female respondents accounted for $38.1 \%(59)$ and males accounted for $61.9 \%$ (96) of the total respondents.

Our data indicated that $47.7 \%$ of the respondents routinely used root-end filling material after an apical resection, whereas $9 \%$ of them never used it (Figure 1A). Twenty percent of the respondents who did not use root-end filling material reported that they did not believe in the necessity of its use. The majority of them $(69.4 \%)$ could not use root-end filling material due to technical deficiencies or the absence of the material in their clinic. The remaining percentage of the personal views generally pointed out that high quality root canal treatment is adequate. Moreover, in such cases, placing a root-end filling material would extend the operating time unnecessarily.

\section{Table 1. Sample questionnaire used in this study}

1. Age (please indicate)

2. Gender

- Male

- Female

3. Please indicate as appropriate

- Resident

- Specialist

4. Years of clinical practice since graduation?

- $0-5$

- $6-10$

- $11-15$

- $16-20$

5. Which type of institution best describes your working situation?

- Private clinic

- Public oral and dental health center

- Private foundation faculty of dentistry

- Public faculty of dentistry

6. How often do you perform root-end resections per month?

- $<20 \%$

- $20-40 \%$

- $40-60 \%$

- $60-80 \%$

- $>80 \%$

7. Do you use root-end filling material after you perform an apical resection? (If "Yes" is selected, skip to question 9.)

- Yes (Always)

- No (Never)

- Sometimes

8. If you do not use root-end filling material after apical resections, what is your reason for this?

- I do not believe in the necessity of root-end filling material use

- Technical deficiencies (difficult surgical access and absence of sophisticated armamentarium designed for periapical surgery) or the absence of a suitable material

- Other (please indicate)

9. Which type of material do you use for retrograde filling?

- Amalgam

- Zinc oxide eugenol-based materials like intermediate restorative material or super ethoxy benzoic acid

- Glass ionomer cement

- Composite

- Calcium silicate-based materials like mineral trioxide aggregate or biodentine

- Other (please indicate) 


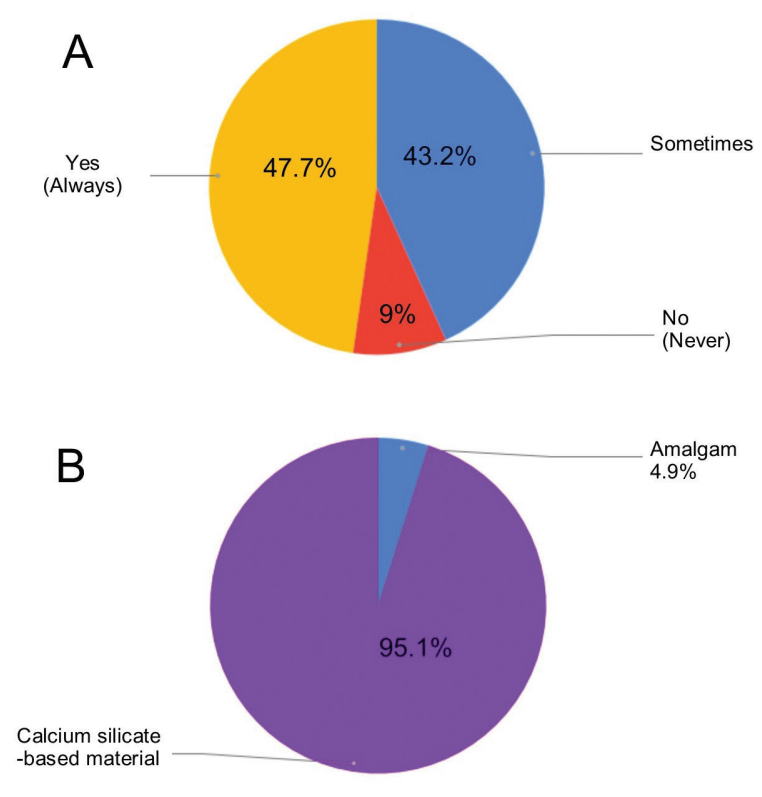

Figure 1. A) Results of question 7: Do you use root-end filling material after you perform apical resections? (B) Results of question 9: Which type of material do you use for retrograde filling?

Distribution of other demographic variables is given in Table 2 and association between these surgeon demographics and use of root-end filling material are given in Table 3. More than half of the residents routinely used root-end filling material (53.3\%) while $39.7 \%$ of the specialists applied rootend filling material. The percentage of not using root-end filling material was lower for residents than specialists $(p=0.001)$.

Regarding clinical experience, there was an association between the use of root-end filling material and the time elapsed since the completion of dental school graduation $(p=0.011)$. More than half of the $<5$ years experienced oral surgeons reported that they routinely use root-end filling material (52.4\%).

There was no association between the type of institution and the use of root-end filling material $(p=0.063)$. Also, we found no association between the frequency of root-end resections performed per month and the use of root-end filling material $(p=0.558)$.

\begin{tabular}{|c|c|c|}
\hline \multicolumn{2}{|l|}{ Demographic variables } & n (\%) \\
\hline \multicolumn{2}{|l|}{ Resident } & 92 (59.4\%) \\
\hline \multicolumn{2}{|l|}{ Specialist } & $63(40.6 \%)$ \\
\hline \multirow{4}{*}{$\begin{array}{l}\text { Years in practice since } \\
\text { dental school }\end{array}$} & $0-5$ years & $84(54.2 \%)$ \\
\hline & $6-10$ years & $43(27.7 \%)$ \\
\hline & $11-15$ years & $17(11 \%)$ \\
\hline & $16-20$ years & $11(7.1 \%)$ \\
\hline \multirow{4}{*}{ Type of institution } & $\begin{array}{l}\text { Public oral and } \\
\text { dental health center }\end{array}$ & $21(13.5 \%)$ \\
\hline & $\begin{array}{l}\text { Public faculty of } \\
\text { dentistry }\end{array}$ & $91(58.7 \%)$ \\
\hline & $\begin{array}{l}\text { Private foundation } \\
\text { faculty of dentistry }\end{array}$ & $7(4.5 \%)$ \\
\hline & Private clinic & $36(23.3 \%)$ \\
\hline \multirow{2}{*}{$\begin{array}{l}\text { Average frequency of } \\
\text { root-end resections } \\
\text { performed per month }\end{array}$} & $<20 \%$ & $128(83.1 \%)$ \\
\hline & $20-40 \%$ & 26 (16.9\%) \\
\hline
\end{tabular}

Most of the participants who used root-end filling material preferred a calcium silicate-based material (95.1\%). The respondents rarely used amalgam for the root-end filling material (4.9\%) (Figure 1B). Associations between the preferred root-end filling material and surgeon demographics were identified in Table 4. The great majority of residents (96.7\%) preferred calcium silicate-based material for rootend filling and $91.7 \%$ of the specialists used MTA like material $(p=0.001)$.

There was an association between the preferred root-end filling material and clinical experience $(p=0.001)$. Great majority of $<5$ years experienced oral surgeons $(96.5 \%)$ reported that they use calcium silicate-based material whereas $62.5 \%$ of $15-20$ years experienced oral surgeons preferred calcium silicatebased material. $37.5 \%$ of the latter reported that they use amalgam for root-end filling.

We found no association between preferred root-end filling material and clinical practice setting $(p=0.434)$. Also, there was no association between the frequency of root-end resections performed per month and the type of root-end filling material $(p=0.781)$. 


\begin{tabular}{|c|c|c|c|c|c|c|c|c|}
\hline & & \multicolumn{3}{|c|}{$\begin{array}{l}\text { Use of root-end filling material after apical } \\
\text { resection }\end{array}$} & \multirow[t]{2}{*}{ Total } & \multirow[t]{2}{*}{$x^{2}$} & \multirow[t]{2}{*}{ df } & \multirow[t]{2}{*}{$p$} \\
\hline & & Sometimes & Yes & No & & & & \\
\hline \multicolumn{2}{|l|}{ Resident } & 49 (53.3\%) & $41(44.6 \%)$ & $2(2.2 \%)$ & $92(100 \%)$ & \multirow{2}{*}{13.326} & \multirow{2}{*}{2} & \multirow{2}{*}{$0.001^{*}$} \\
\hline \multicolumn{2}{|l|}{ Specialist } & $25(39.7 \%)$ & $26(41.3 \%)$ & $12(19 \%)$ & $63(100 \%)$ & & & \\
\hline \multirow{4}{*}{$\begin{array}{l}\text { Years in practice } \\
\text { since dental school }\end{array}$} & $0-5$ years & $44(52.4 \%)$ & $39(46.4 \%)$ & $1(1.2 \%)$ & $84(100 \%)$ & \multirow{4}{*}{16.620} & \multirow{4}{*}{6} & \multirow{4}{*}{$0.011^{*}$} \\
\hline & $6-10$ years & $18(41.9 \%)$ & $17(39.5 \%)$ & $8(18.6 \%)$ & $43(100 \%)$ & & & \\
\hline & $11-15$ years & $9(52.9 \%)$ & $6(35.3 \%)$ & $2(11.8 \%)$ & $17(100 \%)$ & & & \\
\hline & $16-20$ years & $3(27.3 \%)$ & $5(45.5 \%)$ & $3(27.3 \%)$ & $11(100 \%)$ & & & \\
\hline \multirow{4}{*}{ Type of institution } & $\begin{array}{l}\text { Public oral and } \\
\text { dental health } \\
\text { center }\end{array}$ & 9 (42.9\%) & $8(38.1 \%)$ & $4(19 \%)$ & 21 (100\%) & \multirow{4}{*}{11.953} & \multirow{4}{*}{6} & \multirow{4}{*}{0.063} \\
\hline & $\begin{array}{l}\text { Public faculty of } \\
\text { dentistry }\end{array}$ & $43(47.3 \%)$ & $44(48.4 \%)$ & $4(4.4 \%)$ & 91 (100\%) & & & \\
\hline & $\begin{array}{l}\text { Private } \\
\text { foundation } \\
\text { faculty of } \\
\text { dentistry }\end{array}$ & $6(85.7 \%)$ & $1(14.3 \%)$ & $0(0 \%)$ & $7(100 \%)$ & & & \\
\hline & Private clinic & $16(44.4 \%)$ & $14(38.9 \%)$ & $6(16.7 \%)$ & 36 (100\%) & & & \\
\hline \multirow{2}{*}{$\begin{array}{l}\text { Average frequency of } \\
\text { root-end resections } \\
\text { performed per } \\
\text { month }\end{array}$} & $<20 \%$ & 60 (46.9\%) & 55 (43\%) & $13(10.1 \%)$ & $128(100 \%)$ & \multirow{2}{*}{1.167} & \multirow{2}{*}{2} & \multirow{2}{*}{0.558} \\
\hline & $20-40 \%$ & $14(53.8 \%)$ & $11(42.3 \%)$ & $1(3.8 \%)$ & 26 (100\%) & & & \\
\hline
\end{tabular}

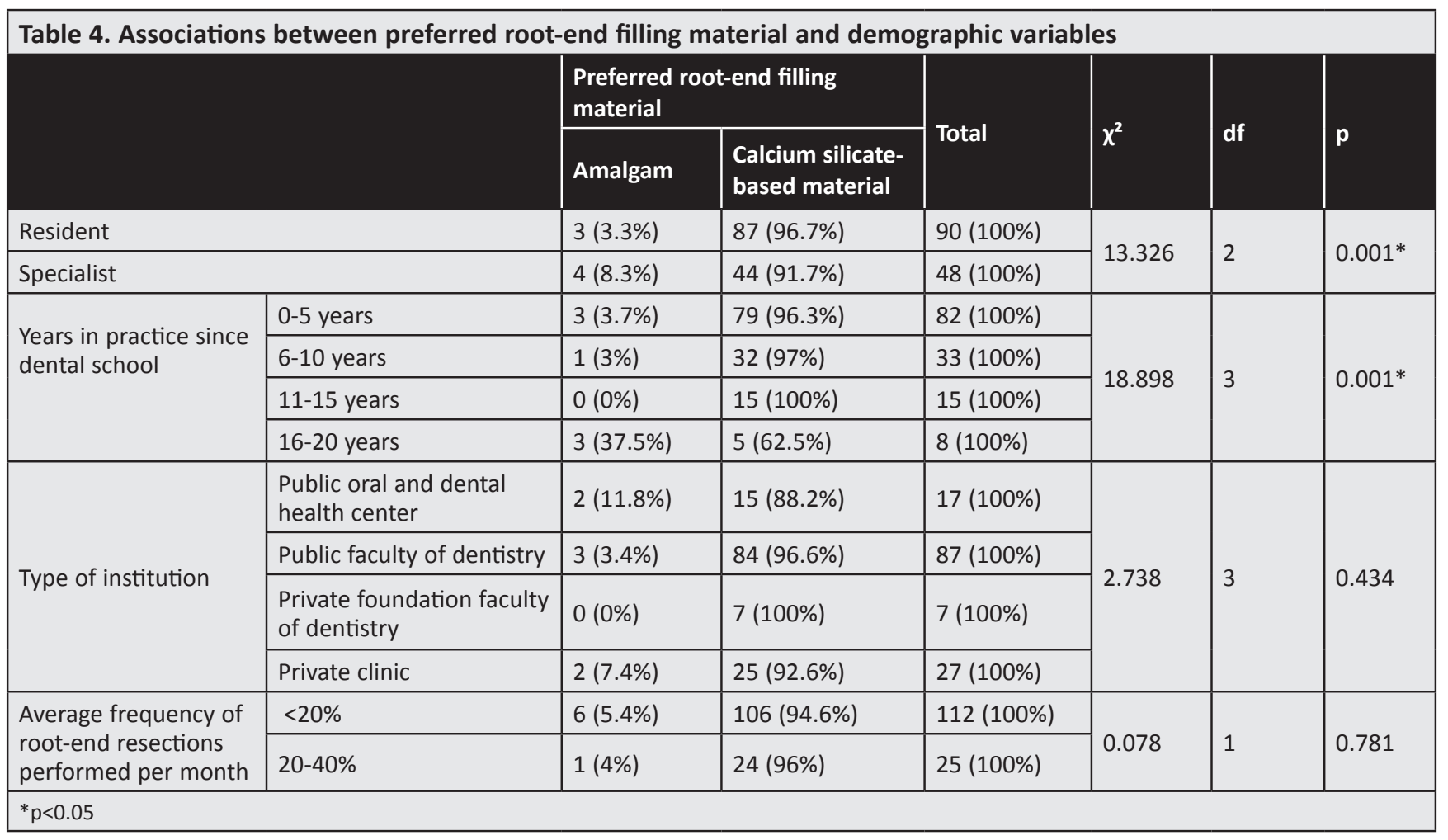




\section{Discussion}

In 2009, a survey study among the members of the American Association of Endodontists indicated that $34.3 \%$ of the active endodontists in the United States referred endodontic surgery to an oral surgeon, while $53.9 \%$ of the respondents did not refer these cases to anyone (11). Although there is no published data, we assumed that the rates of referral to an oral surgeon were much higher in Turkey than in the US based on our observations. The endodontists in Turkey could have avoided doing root-end surgery because of the possible damage to anatomical structures and blood vessels. Additionally, root-end surgery is taught in the oral and maxillofacial surgery residency program in Turkey. Endodontic residents receive training for a limited time (1 month) in the oral and maxillofacial surgery department. The focus is mostly on retrograde filling procedures and dental abscess drainage during their education in the oral and maxillofacial surgery department. Therefore, the target group for this national survey was oral surgeons practicing in Turkey. Additionally, to our knowledge, no study has compared apical surgery outcomes among oral surgeons from different nationalities and among other specialties including endodontics and periodontology. Therefore, we could not know whether Turkish oral surgeons have same, poorer or better success rates. A survey study including multinational oral surgeons and different specialty groups as participants could be further planned to overcome this limitation of the current study.

In contrast to previous survey studies, we preferred to send the URL link of the questionnaire using social media instead of e-mail. According to the "Global Digital Report 2019: Turkey" prepared by "We Are Social" and Hootsuite, internet users spend an average of 2 hours and 46 minutes per day on social networking and messaging platforms, and mobile internet users account for $68 \%$ of the total population (12). Therefore, spending time on the internet facilitates the participants to respond to the survey. High response rate to this survey could be a sign for it.

Tooth extraction, impacted tooth removal, dental implant procedures, the management of odontogenic infections, and the treatment of temporomandibular joint disorders are some of the procedures that oral surgeons deal with in their daily practice. The findings of this national study revealed that the majority of the oral surgeons carried out root-end resections at a rate of $<20 \%$ per month, as expected. To our knowledge, no study has investigated the frequency of root-end surgeries performed by oral surgeons.

Root-end filling placement in the root to seal the end of the root canal is one of the most important steps of apical surgery. Although there have been discrepancies in the necessity of the use of root-end filling material in the past, current evidence suggests that the application of retrograde filling is essential for the success of apical surgery procedures $(5,13)$. The findings of a current randomized clinical trial study showed that resected teeth treated with MTA had a significantly higher healing rate $(96 \%)$ than teeth treated by smoothing the gutta percha root filling (52\%) (5). Another study used a scanning electron microscope to evaluate teeth that were subjected to endodontic surgery and then extracted (13). The authors reported that the most common causative factors for endodontic surgical failure included the absence of root-end filling and an insufficient seal at the interface between the root-end filling and the cavity margin (13). Similarly, another recent study indicated that no root-end filling and incorrect rootend preparation were possible reasons for the failure of endodontic surgery (14). According to the results of this survey, $9 \%$ of the oral surgeons never used rootend filling material after an apical resection, while $43 \%$ of them preferred to apply retrograde filling in some cases. When considering the abovementioned data, the rates of root-end filling usage after an apical resection appeared to be low. One of the reasons for not using root-end filling was that "it was unnecessary". Additionally, technical deficiencies, the absence of a material, and being time consuming were advocated by the oral surgeons in this survey. Therefore, the knowledge of oral surgeons should be updated with regard to root-end filling use, while bearing in mind the current literature. The importance of the technically and biologically adequate management of the root-end should be reinforced.

Some favorable properties, such as its superior sealing ability and biocompatibility over conventional filling materials, make MTA popular in various clinical applications (15-18). According to the results of this survey, more than $90 \%$ of the respondents who used root-end filling preferred calcium silicate-based 
materials, like MTA or biodentine. The high usage rate of MTA among the oral surgeons in Turkey could indicate that certain factors, like the high cost and difficult handling, did not restrict the use of MTA. A recent survey from Australia reported that $47 \%$ of the general dentists and $85 \%$ of the endodontists who performed root-end filling procedures used MTA (19). Another survey study from the Netherlands revealed that the majority of the oral surgeons most widely preferred IRM as a retrograde filling ( $48 \%)$, and the amalgam usage rate was 35\% (20). However, MTA was only used by $2.6 \%$ of Dutch oral surgeons (20).

Our results showed that residents were more likely to use root-end filling material and to prefer calcium silicate-based material after apical resection than specialists. In parallel with this finding, less experienced oral surgeons were more prone to use root-end filling material routinely and choose MTAlike materials. This could be attributed to the fact that residents or younger oral surgeons could have more ethical and ideal approach while treating patients due to being under training program or being controlled by instructors. Although not linearly, while the clinical experience was increasing, the use of root-end filling material was decreasing. While longevity of experience is increasing, oral surgeons may compose a standard protocol for apical surgery, and they may opt in favor of more practical and less time-consuming applications. Neither practice environment nor frequency of performed apical resections did not influence both the use of root-end filling material and the type of filling material preferred.

This study had some limitations. Although the survey questions were explicit about the use of rootend filling material and material preferences, the method and/or instrument used for retrograde cavity preparation and the depth of retrograde cavity were not considered. Future research should explore this issue. Additionally, this study was conducted among Turkish oral surgeons, which can be considered as another limitation. Performing a study including oral surgeons from other countries would have been beneficial to conclude general recommendations.

\section{Conclusion}

According to the findings of this study, a significant number of oral surgeons still do not use rootend filling material after apical surgery for various reasons. Despite the low prevalence of root-end filling use, the majority of the oral surgeons undertaking this procedure prefer to use MTA. Microsurgical techniques with ultrasonic tips should ease root-end preparation and carry the root-end filling material into the cavity. Therefore, oral surgeons' knowledge about this topic should be improved. Better postgraduate education and collaboration with an endodontist would be beneficial for enhancing the success of apical surgery procedures. Moreover, endodontists should be encouraged to perform root-end surgeries.

\section{Acknowledgments}

This study was presented at Turkish Dental Association $25^{\text {th }}$ International Dental Congress in İstanbul, Turkey (September/2019). Authors thank Dr. Hatice Karakas for her help with the statistical analyses.

\section{Ethics}

Ethics Committee Approval: All procedures performed in the study were in accordance with the ethical standards approved by the Human Ethics Committee of the Institutional Review Board (protocol no: 19.04.2019-49).

Informed Consent: Informed consent was not applicable for this type of study.

Peer-review: Externally peer-reviewed.

\section{Authorship Contributions}

Concept: M.B.A., Design: M.B.A., D.M., Supervision: M.B.A., Fundings: M.B.A., S.i.Y., D.M., Materials: M.B.A., S.I.Y., D.M., Data Collection or Processing: S.I.Y., D.M., Analysis or Interpretation: S.I.Y., D.M., Literature Search: S.I.Y., Writing: D.M., Critical Review: D.M.

Conflict of interest The authors declare that they have no conflict of interest.

Financial Disclosure: The authors declared that this study received no financial support.

\section{References}

1. Tsesis I, Faivishevsky V, Kfir A, Rosen E. Outcome of surgical endodontic treatment performed by a modern technique: a meta-analysis of literature. J Endod 2009; 35: 1505-11.

2. von Arx T, Walker WA, 3rd. Microsurgical instruments for rootend cavity preparation following apicoectomy: a literature review. Endod Dent Traumatol 2000; 16: 47-62.

3. Grung B, Molven O, Halse A. Periapical surgery in a Norwegian county hospital: follow-up findings of 477 teeth. J Endod 1990; 16: 411-7. 
4. Rapp EL, Brown CE Jr., Newton CW. An analysis of success and failure of apicoectomies. J Endod 1991; 17: 508-12.

5. Christiansen R, Kirkevang LL, Horsted-Bindslev P, Wenzel A. Randomized clinical trial of root-end resection followed by rootend filling with mineral trioxide aggregate or smoothing of the orthograde gutta-percha root filling--1-year follow-up. Int Endod J 2009; 42: 105-14.

6. von Arx T, Penarrocha M, Jensen S. Prognostic factors in apical surgery with root-end filling: a meta-analysis. J Endod 2010; 36: 957-73.

7. von Arx T. Apical surgery: A review of current techniques and outcome. Saudi Dent J 2011; 23: 9-15.

8. Apaydin ES, Shabahang S, Torabinejad M. Hard-tissue healing after application of fresh or set MTA as root-end-filling material. J Endod 2004; 30: 21-4.

9. Torabinejad $\mathrm{M}$, Hong $\mathrm{CU}$, Lee $\mathrm{SJ}$, Monsef $\mathrm{M}$, Pitt Ford TR. Investigation of mineral trioxide aggregate for root-end filling in dogs. J Endod 1995; 21: 603-8.

10. Torabinejad M, Hong CU, McDonald F, Pitt Ford TR. Physical and chemical properties of a new root-end filling material. J Endod 1995; 21: 349-53.

11. Creasy JE, Mines P, Sweet M. Surgical trends among endodontists: the results of a web-based survey. J Endod 2009; 35: 30-4.

12. Global Digital Report 2019: Turkey. https://wearesocial.com/ global-digital-report-2019.
13. Taschieri S, Bettach R, Lolato A, Moneghini L, Fabbro MD. Endodontic surgery failure: SEM analysis of root-end filling. J Oral Sci 2011; 53: 393-6.

14. Song M, Shin SJ, Kim E. Outcomes of endodontic micro-resurgery: a prospective clinical study. J Endod 2011; 37: 316-20.

15. Kim S, Kratchman S. Modern endodontic surgery concepts and practice: a review. J Endod 2006; 32: 601-23.

16. Torabinejad M, Chivian N. Clinical applications of mineral trioxide aggregate. J Endod 1999; 25: 197-205.

17. Torabinejad M, Hong CU, Pitt Ford TR, Kettering JD. Cytotoxicity of four root end filling materials. J Endod 1995; 21: 489-92.

18. Torabinejad M, Rastegar AF, Kettering JD, Pitt Ford TR. Bacterial leakage of mineral trioxide aggregate as a root-end filling material. J Endod 1995; 21: 109-12.

19. Ha WN, Duckmanton P, Kahler B, Walsh LJ. A survey of various endodontic procedures related to mineral trioxide aggregate usage by members of the Australian Society of Endodontology. Aust Endod J 2016; 42: 132-8.

20. Bronkhorst MA, Berge SJ, Van Damme PA, Borstlap WA, Merkx MA. [Use of root-end filling materials in a surgical apical endodontic treatment in the Netherlands]. Nederlands tijdschrift voor tandheelkunde 2008; 115: 423-7. 